\author{
井口 拳輔, 棚橋 雅幸, 鈴木恵理子 \\ 吉井 直子, 渡邊 拓弥, 千馬 謙亮
}

\begin{abstract}
要 旨
症例は 63 歳, 男性. 検診の胸部 X 線検査で左肺野に不整な結節影を指摘された。胸部 CT 上, 左上葉の過分葉間に径 4 $\mathrm{cm}$ 大の腫瘤影を認めた. FDG-PET では同部位にSUVmax 14.6の FDG 集積があり, 悪性腫瘍が疑われたため診断治療目的 に手術を行った. 左上葉の腫瘍は, 胸壁への浸潤や癒着はなく, 左上葉切除を行った. 病理組織学的に臓側胸膜より発生し た限局性二相型悪性胸膜中皮腫の診断となった。今回我々は過分葉区域間裂の臓側胸膜より発生した限局性悪性胸膜中皮腫 の切除例を経験した．本疾患は稀な疾患と考えられ，文献的考察とともに報告する.
\end{abstract}

索引用語：限局性悪性胸膜中皮腫, 臓側胸膜発生, 手術 localized malignant pleural mesothelioma, visceral pleura, surgery

\section{はじめに}

限局性悪性胸膜中皮腫（localized malignant pleural mesothelioma, 以下 LMPM) は, 明膫に限局した結節性 病変で肉眼的あるいは顕微鏡学的に胸膜表面へのびまん 性進展を認めず, 腫瘍細胞は, 組織学的, 免疫組織化学 的, 超微形態学的にびまん性悪性胸膜中皮腫 (diffuse malignant pleural mesothelioma, 以下 DMPM) と同様の 所見を示す腫瘍と定義されている ${ }^{1)}$. 稀な腫瘍で, 確立さ れた標準的治療法はない。今回我々は, 過分葉区域間裂 の臓側胸膜より発生した LMPM の切除例を経験したの で文献的考察を加えて報告する.

\section{症例}

症 例 : 63 歳男性.

主 訴: 胸部異常陰影.

聖隷三方原病院呼吸器センター外科

原稿受付 2021年 2 月 7 日

原稿採択 2021年 4 月13日
既往歴：高血圧, 狭心症.

家族歴：特記事項なし.

生活歴：喫煙：20本/日 $\times 43$ 年間.

アスベスト曝露歴：なし.

職業歴：トラック運転手.

現病歴：検診胸部 X 線検查で， 1 年前には認められな かった左胸部異常陰影を指摘された。胸部 CT では左上 葉過分葉間に腫瘤影を認め, FDG-PETでは同部位に SUVmax 14.6 の高集積を認めた。悪性腫瘍が疑われ, 手 術加療目的に当科紹介となった。

来院時現症：特記すべきことなし．

血液検查所見 : 腫瘍マーカーを含め明らかな異常を認 めなかった.

胸部単純 $\mathrm{X}$ 線検査 (Fig. 1)：左中肺野に境界明瞭な腫 瘤影を認めた。

胸部 CT 検査 (Fig. 2) : 左上葉の上大区と舌区の過分 葉間に沿って辺縁不整, 境界明膫な $4.3 \mathrm{~cm} \times 1.1 \mathrm{~cm}$ の腫 瘤を認めた。腫瘤は一部胸壁に接していたが明らかな浸 潤所見はなく, 対側胸腔を含め肺実質や胸壁に異常院影 を認めなかった。 また，胸水や縦隔リンパ節腫大も認め 
なかった。

FDG-PET/CT 検査（Fig. 3）：腫瘤に一致して SUV $\max 14.6$ の FDG 高集積を認めたが，その他胸腔内に異 常集積はなく, 遠隔転移を疑う所見も認めなかった.

1 年の経過で出現し増大した病変で, FDG 高集積も認 めたことから悪性孤立性線維性腫瘍や LMPM, 肺癌など の悪性腫瘍を疑った. 診断治療目的に手術の方針とした.

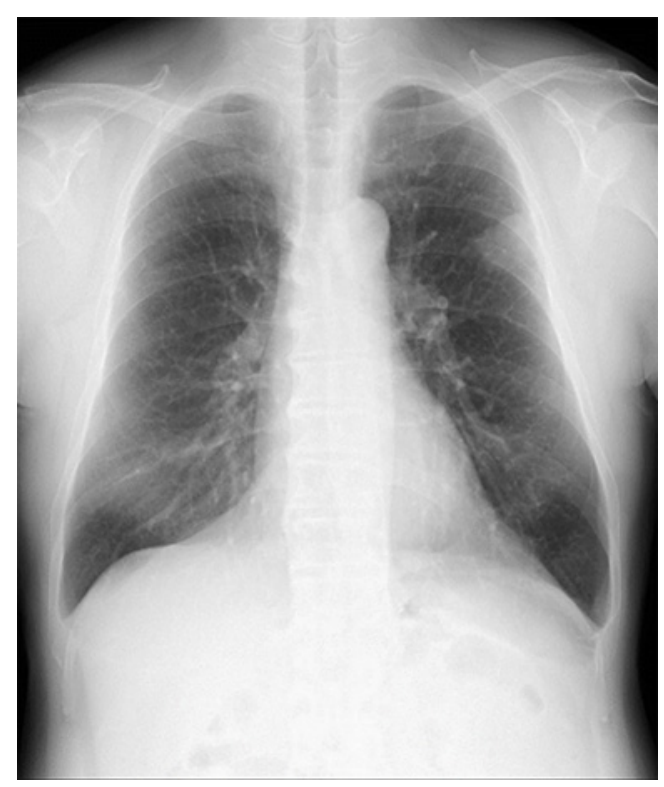

Fig. 1 Chest radiograph showed a mass shadow in the left middle lung field.
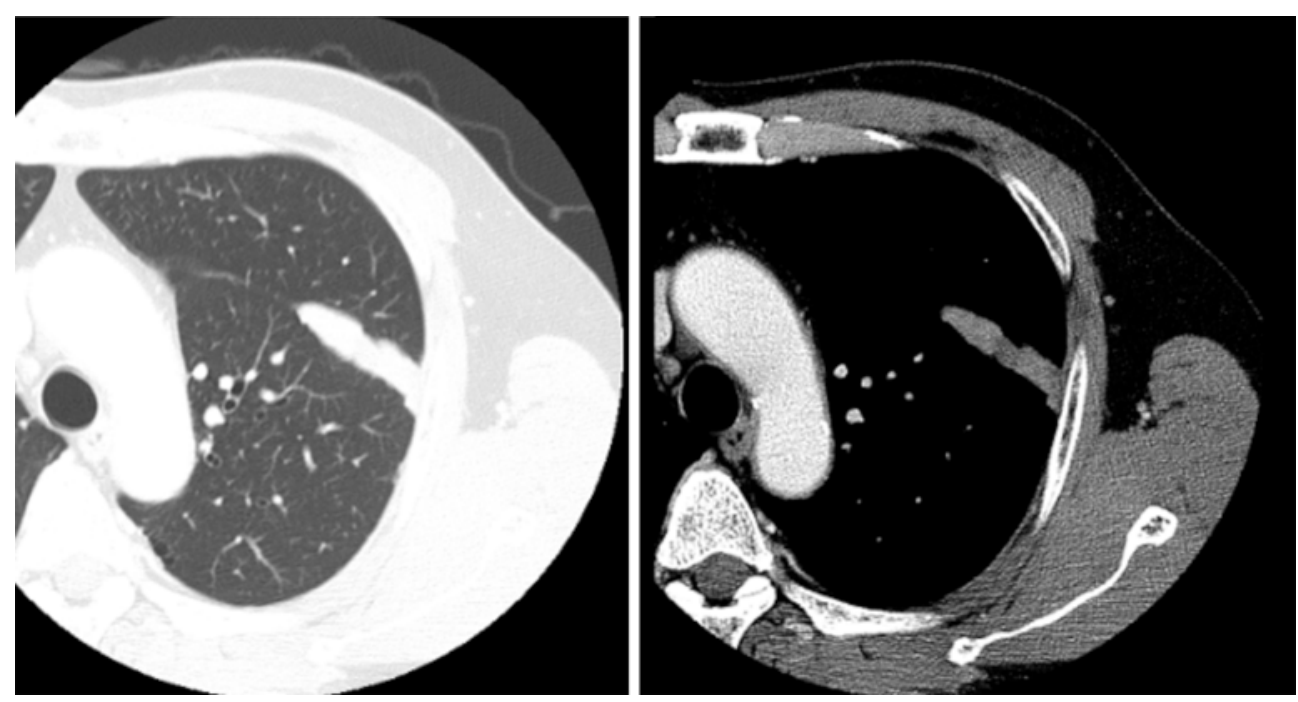

Fig. 2 Chest computed tomography revealed a mass measuring approximately $4.3 \mathrm{~cm}$ in diameter between the hyper-segmented lobes. It touched the chest wall, but there was no infiltration. There was also no significant lymphadenopathy.
手術所見：まず初めに，胸腔鏡にて左胸腔内を観察し た．左肺上葉の上大区と舌区の過分葉間に白色，無茎性 の腫瘍を認めた。胸壁への癒着・浸潤はなく，その他臓 側・壁側胸膜に異常所見を認めなかった. 胸水貯留も見 られず, 胸腔洗浄細胞診にて腫瘍細胞陰性であったので 完全切除可能と判断した. 腋窝切開, 第 4 肋間開胸, 胸 腔鏡補助下に左肺上葉切除とリンパ節郭清を行った。術 中迅速組織診断では悪性腫瘍の結果で, 確定診断までに は至らなかった。

肉眼所見 (Fig. 4)：腫瘍は白色, 弾性硬で, 大きさは $6.7 \times 3.8 \times 1.3 \mathrm{~cm}$ であった. 肺との境界は明暸であった が, 可動性はなかった.

病理学的所見：HE 染色では, 腫瘍は過分葉区域間裂 を埋めるように増殖し, 臓側胸膜から発生していると考 えられた。主に肺外に発育した病変であったが, 一部腫 瘍の内部に肺胞構造を認め, 肺実質への浸潤を示してい た. 紡錘形の腫瘍細胞や類上皮細胞が増殖しており, 腫 瘍細胞は核の大小不同や核形の不整が目立っており, 一 部は storiform pattern を呈していた. また, 一部の腫瘍 細胞は多角形を呈し，上皮性の配列を示していた（Fig. 5)。免疫染色所見（Fig. 6）では，上皮性成分では，CK （AE1/AE3）陽性, WT-1 弱陽性, Calretinin 㓌性, CK 5/6 陰性, D2-40 陰性, STAT6 陰性であり, 肉腫性成分 では, WT-1 陰性であり, その他マーカーは上皮型成分と 同様の結果であった。 また, CEA, TTF-1 はどちらの成 

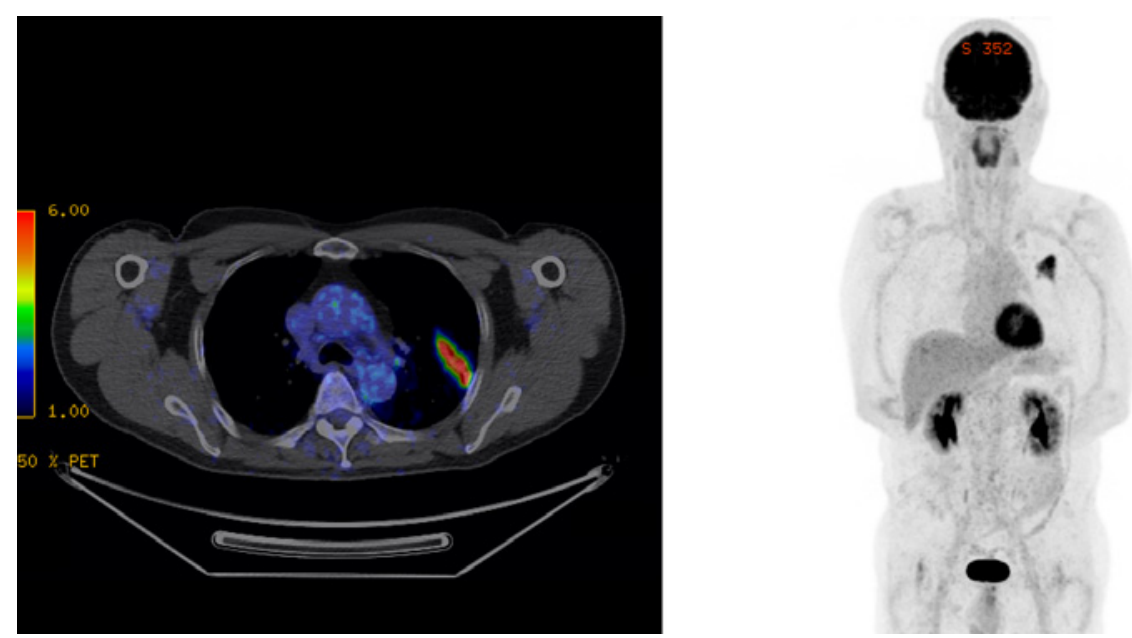

Fig. 3 FDG-PET showed accumulation in the tumor (SUV max: 14.6).
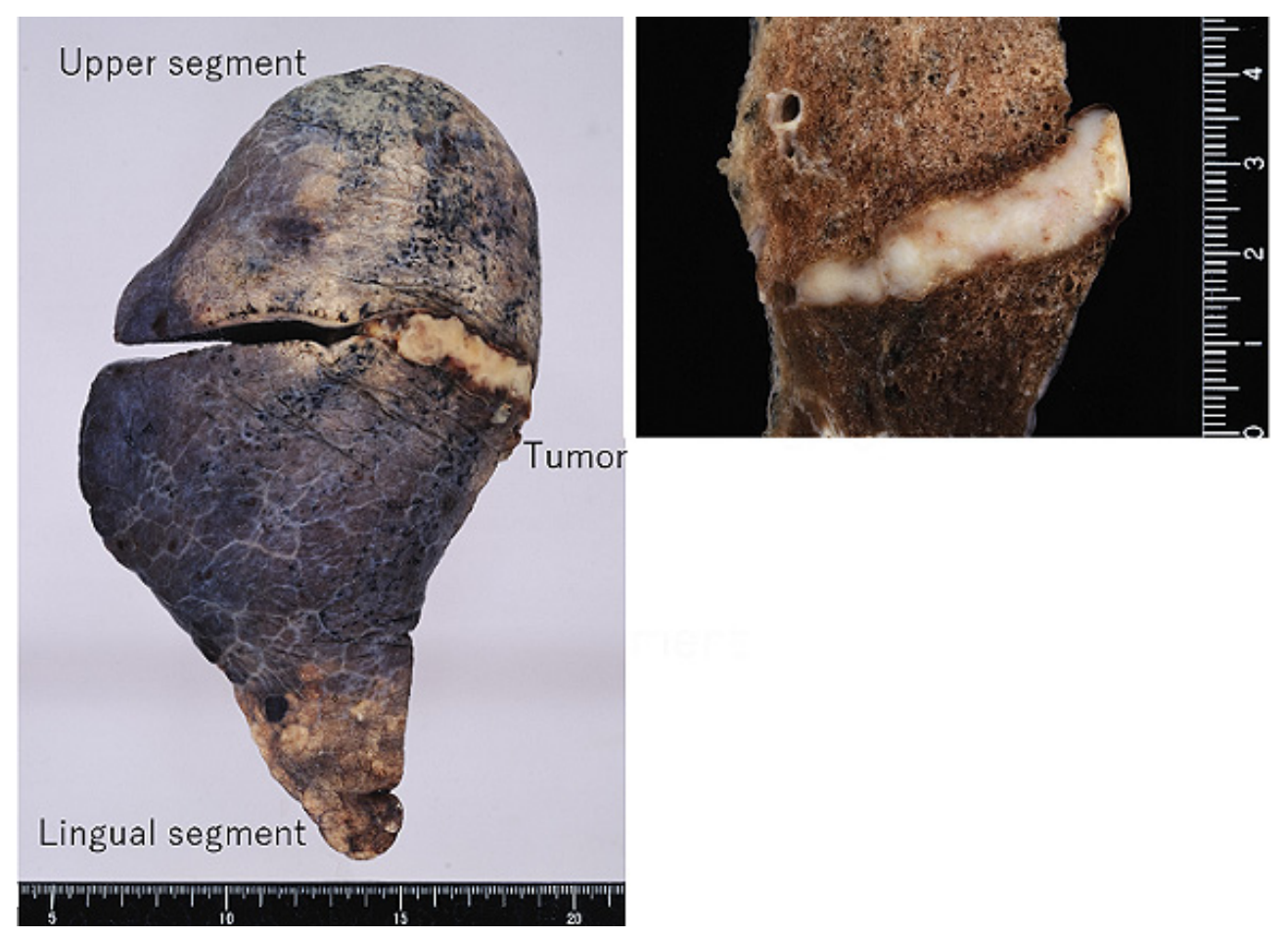

Fig. 4 Macroscopic findings of the resected specimen. A white, elastic-hard tumor measuring $6.7 \times 3.8 \times 1.3 \mathrm{~cm}$ was found in the left upper hypersegmental lobe. No chest wall invasion was observed.

分とも陰性であった. 肉腫性成分が多かったものの, 上 皮性成分も $10 \%$ 以上存在するため, 二相型限局性悪性胸 膜中皮腫の最終診断となった.

経 過：術後合併症なく, 第 8 病日に退院した。完全 切除が得られたため追加治療は行わない方針とした。術
後 1 年 6 カ月経過したが, 無再発, 経過観察中である.

$$
\text { 考察 }
$$

LMPM は, 明瞭に限局した結節性病変で, 肉眼的ある いは組織学的に中皮腔に沿ったびまん性進展はみられな 


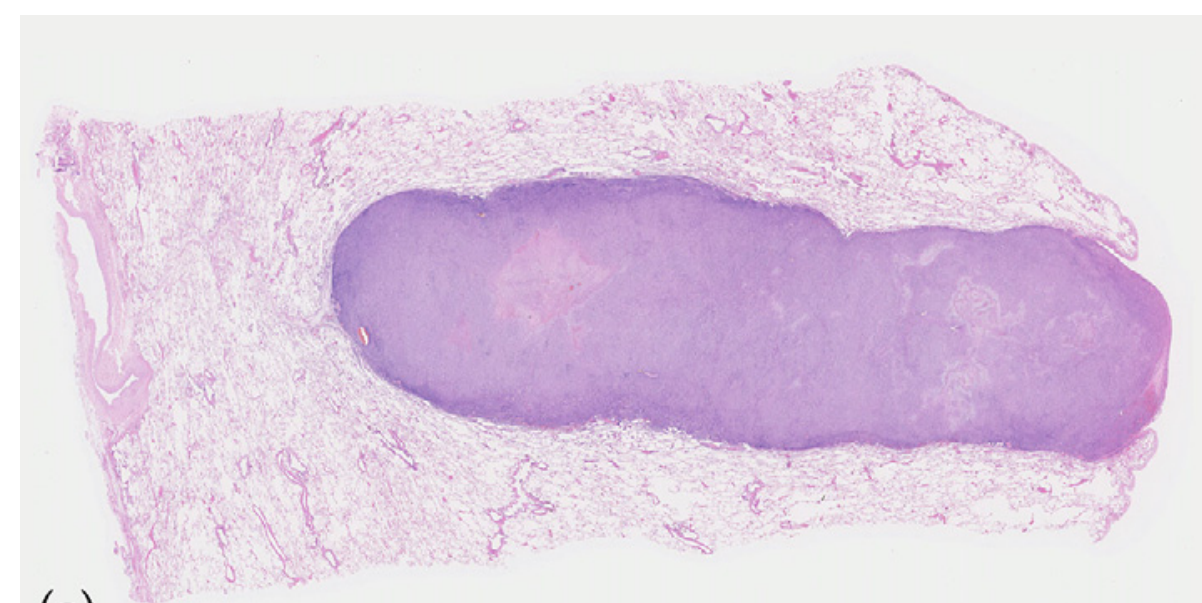

(a)

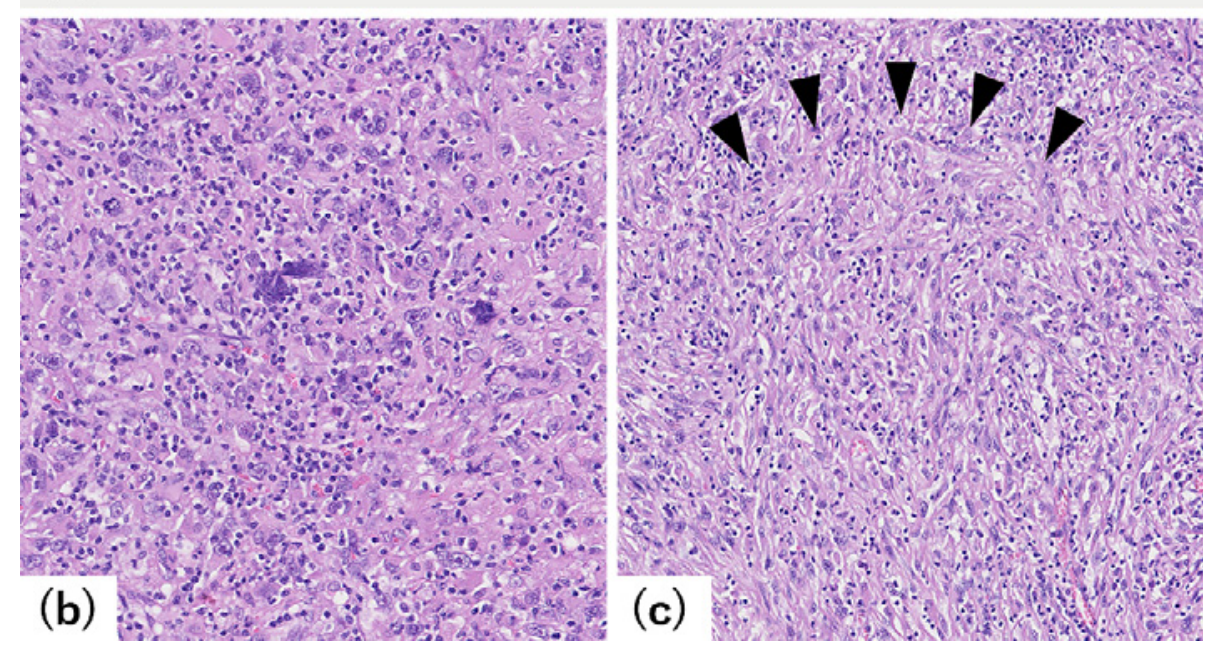

Fig. 5 Pathological findings of the tumor. The tumor had grown to fill the interlobar pleura and originated from the visceral pleura $(\mathbf{a}, \mathrm{HE} \times 0.42)$. It showed an epithelial arrangement, and multinucleated cells were conspicuous $(\mathbf{b}, \mathrm{HE} \times 20)$. Spindle-shaped tumor cells were observed, and some showed a storiform pattern $(\mathbf{c}, \mathrm{HE} \times 10)$.

いが, 組織学的, 免疫組織学的, 超微形態学的には DMPM の所見を示す稀な腫瘍と定義されている ${ }^{1)}$.これ までの報告によると，DMPM と比較し LMPM は，アス ベストに関連している症例が少ないこと, 術後再発形式 として局所再発や遠隔転移が多く, びまん性進展が少な いことなどが特徴として挙げられている2. また, 2 年生 存率を比較すると, DMPM は $25.0 \%$ に対し LMPM は 62.2\%で DMPM より予後良好であった ${ }^{3.44}$.

本症例では, WT-1, Calretinin, D2-40などの中皮腫の 陽性マーカーが強陽性とはならなかった。CK（AE1） AE3）が陽性であるため孤立性線維性腫瘍の可能性は低 いと考えられる. また肉腫型の成分が主であることから， 肉腫型中皮腫や肉腫様癌が鑑別として挙げられるが, $\mathrm{HE}$
染色で多角形の上皮性配列を示す部分を $10 \%$ 以上に認 めたことから，二相型限局性悪性胸膜中皮腫の最終診断 に至った。

LMPM は稀な腫瘍で，その多くは壁側胸膜発生であ る. 今回, 我々が経験したような臓側胸膜発生の LMPM はさらに稀であり, 検索した限りでは, 自験例を加え 7 例の報告のみであった ${ }^{5-8}$ (Table 1)。過分葉間裂から発生 した LMPM にいたっては報告例が見当たらなかった。 臓側胸膜発生 LMPM の 7 例を検討すると, 年齢の中央 值は 68 歳 (42-79歳), 性別は男性 4 例/女性 3 例, 腫瘍 径の平均值は $5.5 \pm 1.4 \mathrm{~cm}$ であった. 全例で手術が施行さ れており, 術式は部分切除 5 例, 肺葉切除 2 例で, 部分 切除術が選択された症例が多数を占めていた。組織型は 


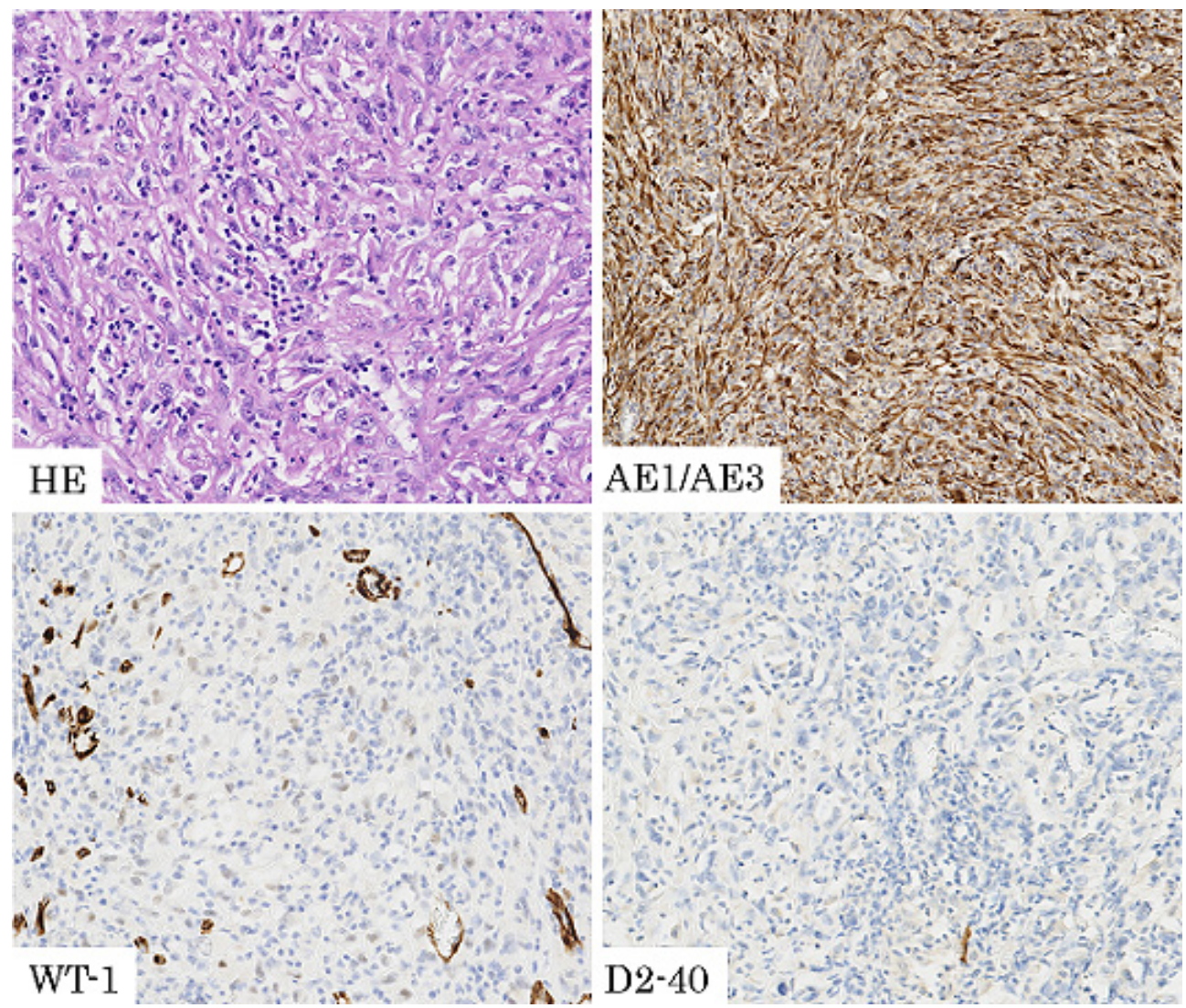

Fig. 6 Immunological findings of the specimen $(\times 20)$. Pathological findings revealed that AE1/AE3 was positive, WT-1 was weak-positive, and D2-40 was negative on immunostaining.

Table 1 Case reports of localized malignant pleural mesothelioma involving visceral pleural development

\begin{tabular}{|c|c|c|c|c|c|c|c|c|}
\hline Author & case & age & $\operatorname{sex}$ & size $(\mathrm{cm})$ & histological & treatment & RFS (mo.) & relapse \\
\hline 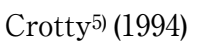 & No.1 & 74 & $\mathrm{~F}$ & 10 & Epithelioid & WR & 18 & $+(\mathrm{bi})$ \\
\hline Narita $^{6)}(2001)$ & No.2 & 68 & M & 10 & Sarcomatoid & WR & 32 & + (ipsi) \\
\hline Iesato $^{7)}(2010)$ & No.3 & 79 & $\mathrm{~F}$ & 8 & Epithelioid & WR & 14 & - \\
\hline \multirow[t]{3}{*}{ Mann $^{8)}(2019)$} & No.4 & 71 & M & 2.2 & Epithelioid & Lobectomy, Che & 35 & + (ipsi) \\
\hline & No.5 & 65 & M & 1.7 & Epithelioid & WR, Che & 21 & + (ipsi) \\
\hline & No.6 & 42 & $\mathrm{~F}$ & 2.6 & Sarcomatoid & WR & 2 & - \\
\hline this case report & No.7 & 63 & M & 4.3 & Biphasic & Lobectomy & 18 & - \\
\hline
\end{tabular}

RFS: relapse-free survival, Che: adjuvant chemotherapy, WR: wedge resection, bi: bilateral pleura, ipsi: ipsilateral pleura

上皮型 4 例, 肉腫型 2 例, 二相型 1 例であった. 2 例で術 後化学療法が行われていた. 無再発期間の中央值は 18 力 月 (2-35 力月) で, 4 例に再発が認められ, 全例胸膜での 再発であった．再発部位の詳細な記載がなく断定的なこ とは言えないが，部分切除を選択したことによる局所再 発の可能性は否定できない. 臓側胸膜発生 LMPM に対
する適切な術式について症例を集積し検討する必要があ る. また本症例では切除した左肺上葉の肉眼的に正常と 思われる胸膜には病理学的にも腫瘍性病変を認めず正常 な胸膜であった．しかし一般的に悪性胸膜中皮腫の初発 部位は壁側胸膜から発生すると考えられていることか $ら^{1)}$ ，肉眼的に正常と思われる壁側胸膜を生検しても良 
かったかもしれない.

LMPM 完全切除後の追加治療については, 明確な指針 はいまだない. Nakas ら ${ }^{9)}$ の報告では, LMPM 切除 10 例を検討し, 補助療法としての化学療法や放射線治療は DMPM 同様に有効であるとしている. 一方, 山田ら ${ }^{10)}$ は LMPM 既報例のなかで術後補助療法の記載のある 28 例 を検討し, 術後無治療群 21 例中 11 例 (52.4\%), 補助療 法群 7 例中 3 例 $(42.9 \%)$ に再発がみられたと報告してお り, 補助療法群でも無治療群と同様の再発率を示してい る.このように, 術後補助療法の意義についてはいまだ 明確ではなく, 術式と同様さらなる検討が必要である.

\section{結語}

左肺過分葉区域間裂の臓側胸膜から発生した二相型の LMPM を経験した. LMPM は外科治療が有効であると 考えられるが確立した治療法はまだない. DMPM と比 較して予後良好とはいえ, 再発例も少なくないため, 症 例を集積し, 適切な術式や術後治療の意義などについて 検討していく必要がある.

\section{謝辞}

稿を終えるにあたり, 病理所見についてご指導いただ きました，東京女子医科大学八千代医療センター病理診 断科廣島健三先生, 聖隷三方原病院病理診断科 小川 博先生に深謝いたします。

\section{利益相反}

本論文に関して申告する利益相反はない。

\section{文献}

1. 石綿 - 中皮腫研究会, 日本中皮腫研究機構, 日本肺癌学会
編. 中皮腫瘍取扱い規約. 第 1 版. 東京: 金原出版；2018.

2. Allen TC, Cagle PT, Churg AM, Colby TV, Gibbs AR, Hammar SP, et al. Localized malignant mesothelioma. Am J Surg Pathol 2005; 29: 866-73.

3. 稲福賢司, 諸星隆夫, 足立広幸, 公盛啓介, 津浦幸夫, 益 田宗孝. 術前に肺癌と診断された限局性悪性胸膜中皮腫 の 1 切除例. 肺癌 2016; 56: 1040-5.

4. 由佐俊和, 伊豫田明, 門山周文, 佐々木一義, 鈴木 実, 山川久美, 他. 多施設共同研究グループによるびまん性悪 性胸膜中皮腫 51 症例の臨床的検討。肺癌 2005; 45: 2417.

5. Crotty TB, Myers JL, Katzenstein AL, Tazelaar HD, Swensen SJ, Chrug A. Localized malignant mesothelioma. A clinicopathologic and flow cytometric study. Am J Surg Pathol 1994; 18: 357-63.

6. 成田久仁夫, 岩波 洋, 日吉晴久, 坪井栄孝. 反復手術に より 12 年の長期生存を得た限局性悪性胸膜中皮腫の 1 例. 日呼外会誌 2001; 15: 490-5.

7. 家里明日美, 藏井 誠, 境澤隆夫, 椎名隆之, 近藤竜一, 吉田和夫, 他. 限局性悪性胸膜中皮腫の 1 例. 日臨外会誌 2010; 71: 1159-64.

8. Mann S, Khawar S, Moran C, Kalhor N. Revisiting localized malignant mesothelioma. Ann Diagn Pathol 2019; 39: 74-7.

9. Nakas A, Martin-Ucar AE, Edwards JG, Waller DA. Localised malignant pleural mesothelioma: a separate clinical entity requiring aggressive local surgery. Eur J Cardiothorac Surg 2008; 33: 303-6.

10. 山田朋子, 関谷充晃, 塩田智美, 徐 仁美, 田辺悠記, 高 橋和久.巨大な単発腫瘤を呈した限局性悪性胸膜中皮腫 の 1 例. 日呼吸誌 2019; 8: 317-21. 


\title{
A case of localized malignant pleural mesothelioma of the visceral pleura
}

\author{
Kensuke Iguchi, Masayuki Tanahashi, Eriko Suzuki \\ Naoko Yoshii, Takuya Watanabe, Kensuke Chiba
}

Division of Thoracic Surgery, Respiratory Disease Center, Seirei Mikatahara General Hospital

Malignant mesothelioma is classified as diffuse and localized malignant mesothelioma according to the mode of extension. Localized malignant mesothelioma is similar to diffuse malignant mesothelioma histologically and immunologically, but has different characteristics. The patient was a 63-year-old male. He was diagnosed with a malignant tumor and underwent surgery for diagnosis and treatment. A tumor was found in the hyperlobulation between the superior division and lingular segments, and there was no invasion or adhesion to the chest wall. We report the diagnosis of a localized biphasic mesothelioma of the visceral pleura because we encountered a rare case.

(C) The Japanese Association for Chest Surgery (JACS) 